\title{
Prostaglandin levels in blood plasma during asthmatic attacks in patients with aspirin idiosyncrasy
}

\author{
J. C. DelaneY* \\ M.B., Ch.B., M.R.C.P. \\ J. B. SMITH $\dagger$ \\ Ph.D. \\ M. J. SILVER $\dagger$ \\ D.Sc. \\ * David Lewis Northern Hospital, Liverpool and † Departments of Medicine and Pharmacology, \\ Cardeza Foundation, Jefferson Medical College, Thomas Jefferson University, \\ Philadelphia, Pa. 19107, U.S.A.
}

\begin{abstract}
Summary
It has been suggested that prostaglandin release is an important factor in the pathogenesis of bronchial asthma. Aspirin inhibits prostaglandin synthesis, yet there are a group of patients, with aspirin idiosyncrasy, who develop asthma after ingestion of aspirin. We measured prostaglandin levels in seven individuals with this syndrome. Only trace amounts of $\mathbf{P G E}_{2}$ and $\mathbf{P G F}_{2 \alpha}$ were found in plasma during asthmatic attacks provoked by aspirin.

\section{Introduction}

Prostaglandins $E_{2}$ and $F_{2 \alpha}$ are normally present in the human lung and bronchi (Anggård, 1965; Karim, Sandler and Williams, 1967). Prostaglandin $F_{2 \alpha}\left(P F_{2 \alpha}\right)$ is released from the lungs of guinea-pigs and rats during anaphylactic reactions (Piper and Vane, 1969), and in man it contracts bronchial smooth muscle in vitro and in vivo (Sweatman and Collier, 1968; Smith and Cuthbert, 1972). Asthmatic patients appear to be remarkably sensitive to inhaled $\mathrm{PGF}_{2 \alpha}$ (Mathé et al., 1973), and it may be that endogenous $\mathrm{PGF}_{2 \alpha}$ plays a significant role in the pathogenesis of bronchial asthma.

Aspirin and indomethacin strongly inhibit prostaglandin synthesis (Vane, 1971; Smith and Willis, 1971) and it has been suggested that, thereby, aspirin has a bronchodilator action.

A group of asthmatics, however, appear to be sensitive to aspirin and develop increased airways obstruction within minutes of aspirin ingestion (Samter and Beers, 1967). This response appears to be a chemically mediated rather than an immunological one, as other analgesics, structurally unrelated to aspirin, have similar effects on these individuals (Smith, 1971). The chemical mediator may well be $\mathrm{PGF}_{2 \alpha}$.
\end{abstract}

In order to determine if asthmatic attacks occurring in this syndrome were associated with a rise in the prostaglandin levels, we measured $\mathrm{PGE}_{2}$ and $\mathrm{PGF}_{2 \alpha}$ levels in the plasma of seven patients during asthmatic attacks precipitated by oral challenge with soluble aspirin.

\section{Method}

Seven patients with aspirin-induced asthma were studied. Previously, these patients had been found, after aspirin ingestion, to have airways obstruction demonstrated by changes in the pulmonary function tests, but subjectively they had been unaware of severe dyspnoea. Clinical features of these patients are outlined in Table 1.

No changes were made in their normal medication.

The FEV \% was calculated from measurements of the forced vital capacity (FVC), and forced expiratory volume in one second $\left(\mathrm{FEV}_{1}\right)$. The maximum breathing capcity (MBC) was also measured. These pulmonary function tests (PFTs) were performed at zero time and at 30-min intervals for $2 \mathrm{hr}$.

In four patients blood was taken for measurement of $\mathrm{PGE}_{2}$ and $\mathrm{PGF}_{2 \alpha}$ levels immediately before the PFTs at zero time.

Soluble aspirin was given to each of the seven patients after the completion of the PFTs at zero time. The dose, varying between $80 \mathrm{mg}$ and $600 \mathrm{mg}$, depended on their previous response to aspirin ingestion.

Airways obstruction invariably occurred at $60 \mathrm{~min}$ with a fall in the FEV \% and MBC. At this time blood was taken for prostaglandin measurements in all seven patients.

In each case blood was taken from an antecubital vein, via a BD 'Vacutainer' system into lithium heparin tubes. The samples were centrifuged 
TABLE 1. Clinical features of seven subjects with aspirin-induced asthma

\begin{tabular}{|c|c|c|c|c|c|c|c|}
\hline Patient & Sex & Age & $\begin{array}{c}\text { Duration } \\
\text { of asthma } \\
\text { (years) }\end{array}$ & $\begin{array}{l}\text { Nasal } \\
\text { polypi } \\
\text { (years) }\end{array}$ & Skin tests & $\begin{array}{l}\text { Other drug } \\
\text { sensitivities }\end{array}$ & Medication \\
\hline S.T. & $\mathbf{M}$ & 24 & 6 & 2 & $\begin{array}{l}\text { House } \\
\text { dust* } \\
\text { Moulds* }\end{array}$ & Nil & Daneral S.A. \\
\hline S.T. & $\mathrm{F}$ & 23 & $2 / 3$ & 一 & - & $\begin{array}{l}\text { Indomethacin } \\
\rightarrow \text { asthma }\end{array}$ & Nil \\
\hline L.W. & $\mathbf{M}$ & 50 & 3 & - & - & Nil & $\begin{array}{l}\text { DSCG } \dagger \\
\text { Tedral S.A. }\end{array}$ \\
\hline L.K. & $\mathbf{F}$ & 41 & 11 & 14 & - & Nil & $\begin{array}{r}\text { Prednisolone } \\
10 \mathrm{mg} / \text { day }\end{array}$ \\
\hline E.S. & $\mathbf{F}$ & 38 & 2 & 15 & - & $\begin{array}{r}\text { Paracetamol } \\
\rightarrow \text { asthma }\end{array}$ & $\begin{array}{l}\text { Prednisolone } \\
2 \mathrm{mg} / \text { day } \\
\text { Beclomethasone } \\
\text { inhaler }\end{array}$ \\
\hline M.C. & $\mathbf{F}$ & 32 & 9 & 4 & - & $\begin{array}{r}\text { Paracetamol } \\
\rightarrow \text { asthma }\end{array}$ & Salbutamol \\
\hline S.L. & $\mathbf{F}$ & 29 & 6 & 5 & $\begin{array}{l}\text { Feathers* } \\
\text { Moulds* }\end{array}$ & Nil & $\begin{array}{l}\text { DSCG } \dagger \\
\text { Prednisolone } \\
5 \mathrm{mg} / \text { day } \\
\text { Beclomethasone } \\
\text { inhaler }\end{array}$ \\
\hline
\end{tabular}

* Mild reaction. $\quad \dagger \mathrm{DSCG}=$ Disodium cromoglycate.

without delay to prepare plasma. A $5 \mathrm{ml}$ sample of plasma was added to $2 \mathrm{ml}$ ethanol to help preserve the prostaglandins before their extraction.

\section{Technique of analysis}

The prostaglandins were extracted essentially as described by Unger, Stamford and Bennett (1971) and separated into PGF and PGE fractions on silicic acid columns (Zusman, Caldwell and Speroff, 1972). The PGE content was determined by bioassay on the rat stomach strip (Silver et al., 1972), and the PGF $_{2 \alpha}$ content by radioimmunoassay using an antiserum generated against a $\mathbf{P G F}_{2 \alpha}$ albumin conjugate (Caldwell et al., 1971).

\section{Results}

The changes in the PFTs in response to aspirin ingestion are outlined in Table 2.

The levels of plasma $\mathrm{PGE}_{2}$ were less than 350 $\mathrm{pg} / \mathrm{ml}$, and the levels of plasma $\mathrm{PGF}_{2 \alpha}$ were less than $175 \mathrm{pg} / \mathrm{ml}$ in all the samples studied. In other words, the levels of $\mathrm{PGE}_{2}$ and $\mathrm{PGF}_{2 \alpha}$ were not raised.

\section{Discussion}

It has been suggested that prostaglandin release may play a significant role in the pathogenesis of bronchial asthma (Mathé et al., 1973). Aspirin ingestion in aspirin-sensitive individuals provokes severe asthmatic attacks and would be expected, therefore, to be associated with raised levels of $\mathrm{PGF}_{2 \alpha}$. However, from our results, it would appear that only trace amounts of $\mathrm{PGE}_{2}$ and $\mathrm{PGF}_{2 \alpha}$ are present in the circulation during such attacks, and that some other mechanism is responsible for the production of asthma in these individuals.

On the other hand, these results are insufficient to disprove the hypothesis of Mathé et al. (1973) that release of $\mathbf{P G F}_{2 \alpha}$ from lung tissue plays a significant part in bronchial asthma. Firstly, in some of the

TABLE 2. Changes in pulmonary function tests after aspirin ingestion in seven subjects with aspirin idiosyncrasy

\begin{tabular}{|c|c|c|c|c|c|c|c|c|}
\hline \multirow[b]{2}{*}{ Patient } & \multirow[b]{2}{*}{ Sex } & \multicolumn{2}{|c|}{ FEV percentage } & \multicolumn{2}{|c|}{ MBC litres/min } & \multirow{2}{*}{$\begin{array}{l}\text { Aspirin } \\
\text { dose }(\mathrm{mg})\end{array}$} & \multicolumn{2}{|c|}{$\begin{array}{l}\text { Sample taken for } \\
\text { measurements of } \\
\text { prostaglandin levels }\end{array}$} \\
\hline & & $0 \mathrm{~min}$ & $60 \mathrm{~min}$ & $\overline{0 \text { min }}$ & $60 \mathrm{~min}$ & & $0 \mathrm{~min}$ & $60 \mathrm{~min}$ \\
\hline S.T. & $\mathbf{M}$ & 76 & 56 & 152 & 58 & 300 & Yes & Yes \\
\hline S.T. & $\mathbf{F}$ & 94 & 74 & 110 & 66 & 300 & Yes & Yes \\
\hline L.W. & $\mathbf{M}$ & 46 & 40 & 66 & 52 & 300 & Yes & Yes \\
\hline L.K. & $\mathbf{F}$ & 77 & 67 & 70 & 68 & 600 & Yes & Yes \\
\hline E.S. & $\mathbf{F}$ & 80 & 72 & 113 & 98 & 600 & No & Yes \\
\hline M.C. & $\mathbf{F}$ & 65 & 56 & 65 & 58 & 81 & No & Yes \\
\hline S.L. & $\mathbf{F}$ & 46 & 42 & 64 & 54 & 81 & No & Yes \\
\hline
\end{tabular}


patients examined by these authors, as little as 5-6 pmol PGF $_{2 \alpha}$ produced broncho-constriction. If as little as this was produced by the lungs, it would be impossible to detect an increase in plasma $\mathrm{PGF}_{2 \alpha}$ by our present methods (sensitivity $0.5 \mathrm{pmol} / \mathrm{ml}$ plasma). Secondly, in some patients, PGF $_{2 \alpha}$ inhaled at zero time produced an effect which lasted for $1 \mathrm{hr}$. Since this $\mathrm{PGF}_{2 \alpha}$ may be metabolized very rapidly, the broncho-constrictor effect could persist longer than the prostaglandin. Smith and Cuthbert (1971) have demonstrated a delay in the onset of the broncho-constrictor effect of $\mathrm{PGF}_{2 \alpha}$ in healthy volunteers, suggesting that this prostaglandin may itself be releasing another broncho-constrictor agent, or possibly undergoing metabolism to a more active substance.

In order to be certain that there is not a shortlived increase in plasma $\mathrm{PGF}_{2 \alpha}$ during an asthmatic attack, time-course measurements of $\mathrm{PGF}_{2 \alpha}$ levels should be done using a continuous sampling technique. It would also be of value to measure the levels of 9,11-dihydroxy-15 ketoprost-5-enoic acid, the major metabolite of $\mathrm{PGF}_{2 \alpha}$ (Beguin et al., 1972).

\section{References}

ANGGÅRD, E. (1965) Isolation and determination of prostaglandins in lungs of sheep, guinea-pigs, monkey and man. Biochemical Pharmacology, 14, 1507.

Beguin, F., Bygdeman, M., Green, K., Samuelsson, B., ToppozA, M. \& Wigvist, N. (1973) Analysis of prostaglandin $\mathrm{F}_{2}$ and metabolites in blood during constant intravenous infusion of prostaglandin $F_{2}$ in the human female. Acta physiologica scandinavica, 86, 430.
Caldwell, B.V., Burstein, S., Brock, W.A. \& Speroff, L. (1971) Radioimmunoassay of the F prostaglandin. Journal of Clinical Endocrinology and Metabolism, 33, 171.

Karim, S.M.M., Sandler, M. \& Williams, E.D. (1967) Distribution of prostaglandins in human tissues. British Journal of Pharmacology and Chemotherapy, 31, 340.

Mathé, A.A., Hedqvist, P., Holmgren, A. \& Svanborg, N. (1973) Bronchial hyperreactivity to prostaglandin $F_{2 \alpha}$ and histamine in patients with asthma. British Medical Journal, i, 193.

Piper, P.J. \& VANe, J.R. (1969) Release of additional factors in anaphylaxis and its antagonism by anti-inflammatory drugs. Nature, 223, 29.

SAMTER, M. \& BeERS, R. (1967) Concerning the nature of intolerance to aspirin. Journal of Allergy, 40, 281.

Silver, M.J., Smith, J.B., IngermanN, C. \& Kocsis, J.J. (1972) Human blood prostaglandins: formation during clotting. Prostaglandins, 1, 429.

SMITH, A.P. (1971) Response of aspirin-allergic patients to challenge by some analgesics in common use. British Medical Journal, ii, 494.

Smith, A.P. \& CuthBerT, M.F. (1972) Antagonistic actions of aerosols of prostaglandins $F_{2 \alpha}$ and $E_{2}$ on bronchial muscle tone in man. British Medical Journal, iii, 212.

Smith, J.B. \& Willis, A.L. (1971) Aspirin selectively inhibits prostaglandin production in platelets. Nature, 231, 235.

Sweatman, W.J.F. \& Collier, H.O.J. (1968) Effects of prostaglandins on human bronchial muscle. Nature, 217, 336.

Unger, W.G., Stamford, I.F. \& BennetT, A. (1971) Extraction of prostaglandins from human blood, Nature, 233, 336.

VANE, J.R. (1971) Inhibition of prostaglandin synthesis as a mechanism of action for aspirin-like drugs. Nature, 233, 336.

Zusman, R., Caldwell, B.V. \& Speroff, L. (1972) Radioimmunoassay of the A prostaglandins. Prostaglandins, 2, 41. 